\title{
Turmeric can Prevent Cochlear Damage Due to Ototoxic Drugs
}

\author{
Tengku S.H. Haryuna ${ }^{1}$, Sari Anggraini ${ }^{2}$ \\ ${ }^{1,2}$ Department of Otorhinolaryngology-Head and Neck, Faculty of Medicine, Universitas Sumatera Utara, Indonesia \\ dr.heydiegmail.com \\ sarianggraini88@yahoo.com
}

\begin{abstract}
The high use of ototoxic drugs, especially antibiotics such as aminoglycosides and anticancer drugs such as cisplatin still can not be avoided as a therapeutic option. The use of ototoxic drugs can cause damage to the cochlea, vestibule, and semicircular canals leading to hearing loss and balance disorders.

Our previous study has found that curcumin extracted from turmeric (Curcuma longa $\mathrm{L}$.) is capable of preventing damage to cochlea of rats exposed to noise at the level of molecular biology (protein level) through the decreased apoptotic index, oxidant status, and increased antioxidant status. Cochlear damage due to ototoxic drugs can occur through the similar pathways, thus we have a strong hypothesis that the cochlear damage due to ototoxic drugs may also be prevented by curcumin.

If it is proven in animal studies, the study could be tested on humans (clinical trials) so that curcumin can be used as a herbal medicine to prevent hearing loss.
\end{abstract}

Keywords - curcumin, ototoxic, cochlea, hearing loss.

\section{INTRODUCTION}

Hearing plays a pivotal role in social relationships and one of the causes of hearing impairment is ototoxic drugs. One type of drug inflicting hearing impairment is gentamicin, an aminoglycoside antibiotic [1]. The incidence of cochlear damage caused by aminoglycoside is equal to $7-90 \%$, its rate varies greatly due to differences in study designs and methodologies [2].

Aminoglycosides are ototoxic drugs, widely prescribed due to their effective antimicrobial action and affordable prices [3]. Aminoglycosides are classified as the basic drugs used to treat gramnegative bacterial infections, but gentamicin can cause permanent damage to the sensory hair cells in humans and mammals [4].

Aminoglycosides have the ability to produce an active metabolite that can catalyze the formation of ROS (reactive oxygen species), a highly reactive compound. The human body has a defense system against ROS in the form of antioxidant agents, namely superoxide dismutase, glutathione and catalase [5].
Aminoglycosides-induced ototoxicity develops from low to high frequency, related to oxidative stress. Aminoglycosides, eg. Gentamicin, may react with iron to produce ROS in the inner ear, resulting permanent damage to hair cells and neurons. Excessive ROS levels trigger the apoptotic pathway, which then produces cell death due to aminoglycoside-induced ototoxicity. Eventhough aminoglycoside-induced ototoxicity is welldocumented, its molecular mechanisms still have not been precisely determined [6].

Noise is defined as an unwanted, unpleasant and disturbing sound since it can potentially cause disruption or damage to the inner ear organs [7]. Continuous noise exposure over an extended period of time causes damage to various structures gradually in the cochlea, initially affects higher frequencies, then spreads to lower frequency [7], [8].

Reference [9] found the increased expressions of HSP-70, TNF- $\alpha$, IL-6, NFkB, TLR-2, TLR-4 and MMP-9 as well as the decreased expressions of Type II and IV Collagen in cochlear fibroblasts of Rattus norvegicus due to noise exposure with frequency of $1-10 \mathrm{kHz}$ in the dose variation of noise intensity of $100 \mathrm{~dB}$ SPL for 15 minutes, 91 - 100 - 110 - $120 \mathrm{~dB}$ SPL for 2 hours.

Curcumin is a yellow pigment belonging to a group of phenolic compounds extracted from the rhizome of Zingiberaceae plant family, including: Curcuma longa Linnaeus (synonymous with Curcuma domestica Valeton or turmeric) and Curcuma xanthorrhiza Roxburgh or Java turmeric, often used as a seasoning and coloring agent [10] .Curcumin is known to have a broad spectrum of biological activities as an antioxidant; antiinflammatory; inhibit initiation, promotion and metastasis of tumor; prevent and treat cancer; 
antiviral; antibacterial; antifungal; antiamyloid; immunomodulator that activates $\mathrm{T}$ cells, B cells, macrophages, neutrophils, NK cells and dendritic cells; has the potential to treat allergies, arthritis, Alzheimer's disease and other chronic diseases mediated through the regulation of various transcription factors, growth factors, inflammatory cytokines, protein kinases and other enzymes [11][13].

According to a number of studies that have been conducted, curcumin has been shown to reduce the expressions of cytokines such as IL-1, IL-2, IL-6, IL8 and chemokines, plays a role in the suppression of NFkB activation [14], inhibits inflammatory processes due to TLR-4 and MyD88 [15], decreases the expressions of MMP-2 and MMP-9 [16], increases the expressions of Type III and IV Collagen [17], inhibits the binding of AP-1 via MEKK1-JNK pathway, blocks the phosphorylation of JNK and c-Jun; cell cycle (cyclin D1 and cyclin E); apoptosis (caspase activation and "downregulation" of anti-apoptosis gene products); proliferation (HER-2, EGFR, AP-1); P13K/AKT survival pathway; invasion (MMP-9 and adhesion molecules); angiogenesis (VEGF); metastasis (CXCR-4); inflammation (NFkB, TNF, COX-2, 5LOX) [10], [18], [19].

\section{PUBLICATION OF RESULTS}

In previously published studies, the authors have proved that curcumin is able to prevent damage to the cochlear fibroblasts via several pathways, namely inflammatory, oxidative metabolic and apoptotic pathways. The studies were divided into 4 groups using 24 male Wistar rats (Rattus norvegicus), which consisted of group 1 (control), group 2 (exposed to noise of $100 \mathrm{~dB} 2$ hours per day for 14 days), group 3 (exposed to noise of $100 \mathrm{~dB} 2$ hours per day followed by the administration of $50 \mathrm{mg}$ curcumin for 14 days) and group 4 (exposed to noise of $100 \mathrm{~dB} 2$ hours per day followed by the administration of $100 \mathrm{mg}$ curcumin for 14 days). Results of the study has found that curcumin is able to increase the expressions of SOD and CAT concentration [20]; decrease the expressions of MDA and $\mathrm{H}_{2} \mathrm{O}_{2}$ concentration [21]; decrease the expressions of calcineurin, NFATc1, apoptotic index
[22]; and decrease the expressions of AP-1 [23] on cochlear fibroblasts of Rattus norvegicus.

\section{ADVANCED STUDY}

Histopathologically, similar findings are detected between cochlear damage due to noise exposure and cochlear damage due to ototoxicity. Cochlear histopathological damage caused by aminoglycosides, macrolides, cisplatin and loop diuretics may demonstrate damage to the hair cells, stria vascularis, degeneration of VIII nerve fibers and spiral ganglion cells [24]-[26].

Those findings make the authors believe that damage to cochlear fibroblasts caused by ototoxicity can also be prevented with curcumin.

\section{HYPOTHESIS}

Curcumin can prevent damage to cochlear fibroblasts caused by ototoxicity.

\section{REFERENCES}

[1] C. L. Baggio, A. F. Silveira, M. A. Hyppolito, F. F. Salata and M Rossato, "A functional study on gentamicin-related cochleotoxicity in its conventional dose in neworns," Braz J Otorhinolaryngol, vol. 76 (1), pp. 91-5, 2010.

[2] L. Petersen and C. Rogers, "Aminoglycoside-induced hearing deficits of cochlear ototoxicity," South African Family Practice, vol. 57(2), pp. 77 $82,2015$.

[3] T. J. M. Aquino, J. A. A. Oliveira and M. Rossato, "Ototoxicity and otoprotection in the inner ear of guinea pigs using gentamicin and amikacin: ultrastructural and functional aspects," Rev Bras Otorrinolaringol, vol. 74 (6), pp. 843-52, 2008.

[4] P. M. Uribe, H. Sun, K. Wang, J. D. Asuncion, Q. Wang, C. W. Chen, P. S. Steyger, M. E. Smith and J. I. Matsui, "Aminoglycoside-Induced Hair Cell Death od Inner Ear Organs Causes Functional Deficits in Adult Zebrafish (Danio rerio)," PLoS ONE, vol. 8, pp. 3, 2013.

[5] A. A. Oliveira, M. S. Campos, A. A. B. Murashima, M. Rossato, M. A. Hyppolito and J. A. A. Oliveira, "Persistence of otoprotective effect. How long does otoprotection against amikacin lasts?," Braz J Otorhinolaryngol, vol. 78 (6), pp. 47-50, 2012.

[6] D. Wrzesniok, A. Beberok, M. Otreba and E. Buszman, "Impact of Gentamicin on Antioxidant Enzymes Activity in HEMn-DP Cells," Acta Poloniae Pharmaceutica- Drug Research", vol. 72 (3), pp. 447-53, 2015

[7] Kuntodi. (2007). Gangguan pendengaran akibat bising. [Online]. Available: http://audiologiind.blogspot.com/2012/08/gangguanpendengaran-akibat-kebisingan .html

[8] S. S. Nandi and S. V. Dhatrak, "Occupational noise-induced hearing loss in India," Indian J Occup Environ Med, vol. 12(2), pp.53-6,2008

[9] N. Purnami, "Efek pajanan bising terhadap peningkatan HSP 70, TNF $\alpha$, TLR-2 dan TLR-4 pada fibroblast koklea Rattus norvegicus," Doctoral dissertation, Universitas Airlangga, Surabaya, Indonesia, 2009.

[10] J. Trujillo, L. F. Granados-Castro, C. Zazueta, A. C. Anderica-Romero, Y. I. Chirino and J. Pedraza-Chaverri, "Mitochondria as a target in the therapeutic properties of curcumin," Arch Pharm Chem Life Sci, vol. 347(12), pp.873-84, 2013.

[11] J. M. Ringman, S. A. Frautschy, G. M. Cole, D. L. Masterman and J. L. Cummings, "A potential role of the curry spice curcumin in Alzheimer's disease," Current Alzheimer Research, vol. 2(2), pp.1-6, 2005.

[12] B. B. Aggarwal, C. Sundaram, N. Malani and H. Ichikawa,"Curcumin: the Indian solid gold," Adv Exp Med Biol, vol. 595, pp.1-75, 2007. 
[13] D. Yan, M. E. Geusz and R. J. Jamasbi, "Properties of Lewis lung carcinoma cells surviving curcumin toxicity," Journal of Cancer, vol. 3, pp.32-41, 2012.

[14] C. B. Johnson, and A. N. Mattia. (2006). Curcumin. [Online]. Available: http://www.inchem.org/documents/jecfa/jecmono/v35je09.htm

[15] A. Lubbad, M. A. Oriowo and I. Khan, "Curcumin attenuates inflammation through inhibition of TLR-4 receptor in experimental colitis," Mol Cell Biochem, vol. 322(1-2), pp. 127-35, 2009.

[16] J. H. Hong, K. S. Ahn, E. Bae, S. S. Jeon and H. Y. Choi, "The effects of curcumin on the invasiveness ofprostate cancer in vitro and in vivo," Prostate Cancer and Prostatic Diseases, vol. 19, pp.147-52, 2006.

[17] H. Y. Bao, R. H. Chen, S. M. Huang, X. Q. Pan and L. Fei, "Curcumin inhibited the proliferation and extracellular matrix production of human mesangial cells," Zhonghua Er Ke Za Zhi, vol. 41(11), pp.822-6,2003.

[18] B. B. Aggarwal and S. Shishodia, "Molecular targets of dietary agents for prevention and therapy of cancer," Biochem Pharmacol, vol. 71(10), pp.1397-421, 2006.

[19] O. Naksuriya, S. Okonogi, R. M. Schiffelers and W. E. Hennink, "Curcumin nanoformulations: A review of pharmaceutical properties and preclinical studies and clinical data related to cancer treatment," Biomaterials, vol. 35, pp. 3365-83,2014.

[20] T. S. H. Haryuna, W. Riawan, M. Reza and A. R. Saragih, "Modulation of antioxidant status by curcumin prevents cochlear damage after noise exposure," Journal of Chemical and Pharmaceutical Research, vol. 7(11), pp. 593-7,2015

[21] T. S. H. Haryuna, W. Riawan, M. Reza, N. Purnami and A. Adnan, "Curcumin prevents cochlear oxidative damage after noise exposure,' International Journal of Pharmacy and Pharmaceutical Sciences, vol. 8(1), pp. 175-8, 2016.

[22] T. S. H. Haryuna, W. Riawan, A. Nasution, S. Ma'at, J. Harahap and I. Adriztina, "Curcumin reduces the Noise-Exposed Cochlear Fibroblasts Apoptosis," International Archives of Otorhinolaryngology, vol. 20(4), pp. 370-6, 2016.

[23] T. S. H. Haryuna, R. Lutan, F. A. A. Taufika, R. Anggraeni and T. S. H. Zubaidah, "Effect of Curcuma longa L. Extract on AP1 Expression in Rat Cochlear Fibroblasts Under Noise Conditions," Journal of Chinese Pharmaceutical Sciences, vol. 25 (9), pp. 690-4, 2016.

[24] J. Sturgeon, Clinical Uses of Cisplatin, 1st ed., P. S. Roland and J. A Rutka, Eds. Hamilton, London: BC Decker, Inc, 2004.

[25] N. Prepageran, A. R. Scott and J. A. Rutka, Ototoxicity of Loop Diuretics, 1st ed., P. S. Roland and J. A. Rutka, Eds. Hamilton, London: BC Decker, Inc, 2004.

[26] C. Rotstein. and L. Mandell. Clinical Aminoglycoside Ototoxicity, 1st ed., P. S. Roland and J. A. Rutka, Eds. Hamilton, London: BC Decker, Inc, 2004. 